\title{
Jewish Law, Roman Law, and the Accordance of Hospitality to Refugees and Climate-Change Migrants
}

\author{
Gilad Ben-Nun
}

ABSTRACT: This article examines Jewish law's approach to forced migration. It explains the difference under Jewish law between forced migration brought about by disasters and the state of being a refugee-which is directly associated with war and armed conflict. It continues by demonstrating how these distinctions influenced the religious Jewish authors of the 1951 Refugee Convention. It concludes with the fundamental distinction between Jewish law and Roman law, concerning the latter's application of a strong differentiation between citizens and migrant foreigners, which under Jewish law was entirely proscribed as per the religious duty to accord hospitality to forced migrants irrespective of their background.

KEYWORDS: climate change, Isaac Lewin, Jewish law, migrant-strangers, non-refoulement, Rashi, refugees, Roman law

According to the United Nations High Commissioner for Refugees (UNHCR), in 2018, the number of displaced people worldwide topped 70 million (UNHCR 2018). With climate change now adding to the drive of forced human displacement, the 1951 Refugee Convention's original protective purview, which was restricted to those affected by war and persecution, might well require amendment to correspond to the new realities of forced migration (McAdam 2010, 2012). Reflecting this insufficiency, in 2012, the Nansen Initiative convened by Norway and Switzerland, and supported by several other countries, began discussing how best to cover human displacement resulting from disasters and climate change (Nansen Initiative 2015). The UN Human Rights Council has recently stressed the relationship between climate change, displacement, and the increase in acute human poverty (Alston 2019). Notwithstanding these developments, states have thus far refused to collectively adapt current refugee definitions to include climate change and natural hazards and disasters as legitimate legal grounds meriting international protections such as non-refoulement (McAdam 2011).

One issue currently being debated is whether disasters and climate change are ontologically on par with direct manmade refugee drivers such as war and persecution (Kälin 2016). The extensive discussions dedicated to these problematics, within the Nansen Initiative and beyond, merely attest to the complications associated with achieving consensus on this issue.

Wishing to shed some historical light on this debate, I would like to briefly delve into the ancient origins of the distinction between forced human migration, which is the result of natural hazards and disasters, and refugees who are persecuted or who flee war in fear of persecution. My research objective here is simple and straightforward: I wish to demonstrate that the contemporary debates concerning whether or not climate-change migrants differ from war-related 
and persecution-related migrants in terms of their merit for refugee hospitality are certainly not new and date back millennia. I opt to show that this distinction between both categories of forced migrants already existed both in the Hebrew Bible and within the ancient stipulations of Roman law. Lastly, I wish to demonstrate the difference with which both of these legal systems address forced migrants from both categories.

In search for the definitional difference between these two categories of displaced people as they appear in the Hebrew Bible, I propose to follow the specific linguistic qualities addressing these two categories within the Torah-the Bible's oldest Jewish legal codex comprising the five books of the laws of Moses (Genesis, Exodus, Leviticus, Numbers, and Deuteronomy). As the biblical sources presented in this article clearly demonstrate, commensurate to modern-day distinctions, the distinction between manmade causes for human plight (war, armed conflict, and persecution) and natural forces (such as drought or famine) that brought about human migration were well known to the ancients. The Hebrew Bible does indeed refer to both categories distinctly. Yet despite the existence of such distinctions, under Jewish law, both categories of forced migrants were seen as equal in their right for refugee protection: those resulting from war and persecution as well as those resulting from climatic or natural hazards or disasters.

I begin this study with an in-depth exploration of the etymological and consequently conceptual notion of a refugee (in Hebrew פליט) as opposed to the migrant stranger born in another country (in Hebrew גר). I continue with the important contribution of the Jewish Holocaustsurviving authors of the 1951 Refugee Convention to the elaboration of its Non-Refoulement principle (Article 33) as based upon the precepts of biblical Jewish law. I conclude this article with insights from the protection of refugees the Israeli Supreme Court mentioned in its 1983 investigative report following the Sabra and Shatila massacres of Palestinian refugees in West Beirut during the 1982-84 Lebanon War.

As I have demonstrated elsewhere, several of the key authors who drafted the 1951 Refugee Convention were Holocaust survivors who, based on their own traumatic experiences, came to elaborate some of the Convention's most humane stipulations (Ben-Nun 2017a: 22-33). These included Article 3, which prohibits discrimination, and the absolute prohibition on refoulement (i.e., returning refugees to places where their life or liberties are endangered) (Ben-Nun 2014). Indeed, both Jacob Robinson and Rabbi Isaac Lewin who authored these articles were deeply inspired by biblical modes of thinking when they drafted them. In Robinson's case, this biblical thinking was paramount in his argument in favor of Israel's obligations (as Robinson saw them) to compensate Palestinian refugees from 1948 for their lost assets (Ben-Nun 2014: 121n35). I therefore elaborate further upon the influence of the biblical distinction between manmade war and disasters-one that came to influence Rabbi Dr. Isaac Lewin and Jacob Robinson.

I continue with a relevant (and somewhat forgotten) recent application of the attribution of responsibility for the harm inflicted upon refugees caused by war to the government responsible for their condition: the Israeli Supreme Court's investigation into the massacres of Palestinian refugees in the Sabra and Shatila refugee camps of West Beirut during Israel's 1982 Lebanon War (Ben-Nun 2020: 234-235).

I conclude with some observations concerning the fundamental difference between Jewish law and Roman law with regard to the equalizing of rights between citizens and migrant-strangers under the former, as opposed to the stark differentiation of rights between citizens and peregrini (foreigners) under the latter.

As with any ancient text, a good way to fully understand the Jewish view of the qualification of the terms relating to forced migration on the one hand and refugeeness on the other hand is to read this biblical text in the original Hebrew, as this allows for its full understanding via the tracing of the etymological origins of wordings prior to their translation into non-Semitic 
languages. In addition, when engaging with an ancient text such as the Jewish Torah, one is best suited to understand it when reading the text according to its contextual form as it was formulated before being translated and re-edited into other languages. The original Hebrew Torah did not have any divisions into chapter and verse, rather it was divided into books and parshiot (the portions of the Torah read each week). Its reading in this format helps provide the correct context within which the etymological terms of that text were construed and where these words were deliberately placed inside it.

Lastly, there lies the issue of the Torah's reading-alongside its authoritative commentaries. Wishing to follow the manner in which Jewish law would have read the Torah, and seeing as its interpretation is a vital part of its legal codification, in this article I shall rely for the Torah's reading and interpretation upon its most authoritative and universally undisputed commentator-Rashi (Rabbi Shlomo Itzhaki b. 1040 - d. 1105, Troyes). As the late Harvard scholar Isadore Twersky pertinently noted: "Rashi's work was literally epochal given the agreement of subsequent scholars that the basic needs of text commentary had been fulfilled" (Twersky 1997).

\section{The Biblical Origins of the Notion of a "Refugee" and a "Migrant Foreigner"}

To claim that the theme of migration is associated with the Jewish Torah would be an understatement. Abraham's life begins with his migration from Mesopotamia to the holy land via Asia Minor. Driven by climatic conditions of drought and hunger in Israel, Jacob and his sons descend to Egypt. Thanks to the flow of its great river Nile, it has a consistent and unwavering abundance of flowing fresh water, a scarce resource in the arid desert landscape of the Middle East.

Already from its first book of Genesis, the Torah distinguishes rather clearly between a migrant who has arrived in a certain place due to natural causes (famine or drought) and the refugee forced to move by war. Both categories appear within the same bigger context of migration in the "Call to Abraham" ("Go from your country, your people and your father's household to the land I will show you"-Gen. 12:1).

To Hebrew readers, the weekly parasha (portion) under which both terms refugee and migrant stranger first appear is extremely telling: both the word for migrant stranger (ג) and the word for refugee (פליט) first appear in the Torah in the same parasha of Lech Lecha (Go your way). This parasha, which corresponds to six chapters of the book of Genesis (chaps. 12-17, inclusive), begins with God's command to Abraham to leave his native Mesopotamia and go to the land God shall show him-Israel. It continues with Abraham's migration to Egypt on account of a famine in Israel (Gen. 12:9-11), his return from Egypt to Israel (Gen. 13:1-3), the story of Sodom and Gomorrah, and Abraham's war with the kings there. It ends with the covenant binding God and Abraham, which is personified in Abraham's circumcision of himself and his firstborn son Ishmael. Thus, already contextually, few parashiot in the Torah are as associated with migration and forced migration as the parasha of Lech Lecha.

In the Torah, the word for a migrant stranger is גespective English translations of the Hebrew Bible have used at least four different terms to translate this word: "strangers" (BibleNew International Version), "sojourners" (English Standard Version), "resident aliens" (Christian Standard Bible), and "foreigners" (Holman Christian Standard Bible). The first place the גר appears in the Bible is in Genesis 15:13 where God reveals to Abraham that his children shall be enslaved in Egypt before Moses frees them. The seventeenth-century King James translation of the Hebrew Bible, used throughout this article, reads as follows: "And he said unto 
Abraham, know of a surety that thy seed shall be a stranger in a land that is not theirs, and shall serve them; and they shall afflict them four hundred years." The root of the word גelates to residency, as derived from the verb "to reside" (לגור). The first usage of this verb in the Bible is indicative. Earlier on, in the same parasha of Lech Lecha, as Abraham descends to Egypt on account of the famine in Israel, the text explicitly notes that he "went down into Egypt to sojourn there" (לגור שם-Gen. 12:10). Thus, at least for the Hebrew Bible, the word גרי, which denotes the factual condition of being a resident stranger in another country, is deeply and inextricably associated with natural disasters (famine or drought) that drive people away from their "home" settlements to places where their lives might be spared.

The factuality of being driven away from one's traditional home to live elsewhere was finally captured by Rashi in his commentary on the Bible. Rashi does so within the part of the Torah that deals with the legal predicaments obligating Jews vis-à-vis the most vulnerable members of society—the foreigner, the orphan, and the widow—in Exodus 22:20: "Thou shall neither vex a stranger nor oppress him: for ye were strangers in the land of Egypt.” The pronouncement of the vulnerability of the stranger, and the Jewish need to identify with his suffering and hardships, are again espoused to in the next chapter of the book of Exodus: "Also thou shalt not oppress a stranger: for ye know the heart of a stranger, seeing ye were strangers in the land of Egypt" (Ex. 23:9).

The inconsistencies of the English translations of the Bible, switching between terms such as "foreigner," "stranger," and "sojourner" are not to be found in the Hebrew original, which consistently uses the Hebrew term גר. Rashi's medieval commentary to Exodus 22:20 leaves absolutely no room for error as to whom the biblical text refers to by the usage of the term references to גר : a person not born in that country, but who arrived from another country to reside there."

The clear distinction in later Jewish law between the migrant-resident גר תושב and a person who has religiously converted to Judaism known as righteous foreigner גר צדק is a much later distinction from the age of the Talmud (first to fourth centuries CE) and was clearly not in existence during the Israelite period (thirteenth to sixth centuries BCE) to which Rashi's commentary on the Torah relates, hence Rashi's instance that all biblical references to גר גר conform with his definition. The distinction between גר תושב and גר צדק has, in recent years, given ground to some fanatical modern-day interpretations of the word גר גר so as to contemporarily justify the expulsion of refugees from modern-day Israel as if upon Jewish religious grounds. Rashi's commentary here serves as the clearest and most unequivocal refutation of such arguments. The repetitive use of the word גר גרeughout the Torah (mentioned 46 times, with the decree to explicitly love and protect the stranger appearing 36 times), which was subsequently repeated in the Talmud (Bava Meziah 59) serves to demonstrate just how fundamental and inherent this protection really was under ancient Jewish law.

In contrast to the word גר the word "refugee" (פליט) appears rarely in the five books of the Torah. The first instance where this word appears is also in the same parasha of Lech Lecha (albeit in a different chapter) within the context of Abraham's wars against the kings of Sodom and Gomorrah (Gen. 14:1-17). As the war rages on, a refugee (פליט) arrives at Abraham's dwelling in Hebron bearing the news that his nephew Lot along with his entire family had been taken into captivity. Upon receipt of this news, Abraham wages war upon Sodom and frees his nephew and his family. Here again, virtually all the English translations of the Bible fall short of grasping the Semitic root of the word פליט. The Bible's New International Version, the English Standard Version, and the King James Version all translate פליט as one "who had escaped (Jewish Publication Society 1917)." The New American Standard reverts to the word "fugitive." The Christian Standard Bible refers to "one of the survivors." 
Etymologically, the root פ.ל.ט. פליט derom which the word means "to emit," "to eject," or "to discharge." Thus, in Hebrew the word "refugee" implicitly entails a succinct connection to the condition whereby a particle is extracted away and outside from its unitary whole. Yet the method of extraction of this individual, away from their kin and place or dwelling is invariably associated with war and violent conflict. When later in the book of Genesis, Jacob prepares for his meeting with his brother Esau, and fearing that war is upon him due to his previous quarrel with his brother, Jacob splits his encampment in two so that: "If Esau come to the one company, and smite it, then the other company which is left shall escape" (Gen. 32:8-9).

To modern Hebrew speakers, Jacob's words referring the remaining survivors as שארית הפליטה, which literally translates as "the remaining group refuged" or "surviving remnant" (as translated in the Book of Ezra 9:14, and 1 Chronicles 4:43), is significant. It is the exact term used in reference to the surviving remnants of European Jewry freed by the Allies in 1945 after the Holocaust. Following the end of World War II, Jewish humanitarian organizations established a central body mandated to care for the remains of European Jewry housed in displaced persons camps, numbering approximately two hundred thousand Holocaust survivors (Königseder and Wetzel 2001). The roles of Sherit ha-Pletah included the administration of relief services in direct coordination with the United Nations Relief and Rehabilitation Administration (UNRRA), the retrieving of Jewish children hidden during the war in convents and with non-Jewish foster families, and the organization of agricultural training prior to immigration to Israel (Yad Vashem 2020).

The intimate relation between the Hebrew word for refugee (פליט) and war was finally cemented by Rashi. In his commentary to the unique place in the entire Torah where the word "refugees" (פליטים, in the plural) is mentioned, as the text praises the Jewish victory in war over the Moabites, it exalts that the Moabite god Chemosh: "hath given his sons that escaped (פליטים), and his daughters, into captivity" (Num. 21:29). The translation of the Hebrew word פליטים is different in different versions with the King James Version speaking of "his sons that escaped." The American Standard refers here to "his sons as fugitives," while the Christian Standard Bible speaks of "his sons as refugees." Seeing as this is the first time in the entire Torah where the word "refugees" (פליטים) actually appears, Rashi took care to explain it to the readers of his commentary: "refugees: those who flee and refuge from the sword." The association between being a refugee and the causal circumstances of war that brought about this condition are direct and clear-cut.

\section{Religious Jewish Thinking at the 1951 Refugee Convention}

The last decade has seen a considerable widening of our understanding of the driving forces (and drafting forces) that helped shape the wording of the 1951 Refugee Convention (Einarsen 2011). As Irial Glynn, I, and others have all demonstrated, the role of Jewish international jurists such as Paul Weis, Jacob and Nehemiah Robinson, Isaac Lewin, Louis Henkin, and others in the making of this Convention was absolutely paramount to its wording and its adoption (Ben-Nun 2014: 103-109; Giladi 2015; Glynn 2012). The 1951 Refugee Convention's offspring, such as the 1954 Convention on Statelessness and indeed the very nature and existence of UNHCR and its Executive Committee, were also heavily influenced by the work of these Jewish drafters (BenNun 2015a, 2017b).

As I have previously demonstrated, the entire elaboration of the 1951 Refugee Convention's Non-Refoulement clause (today's Art. 33), from its earliest draft at the United Nations Economic and Social Council's Ad Hoc Committee on Statelessness in February 1950, to its final 
endorsement at the Geneva plenipotentiaries' conference in July 1951, was one long and continuous effort on behalf of the Jewish delegates Isaac Lewin, Paul Weis, and most importantly, Jacob Robinson in his final compromise on the limitation to non-refoulement as evident in Article 33's paragraph 2 (Ben-Nun 2015a).

From the vantagepoint of Jewish law, the most important issue concerns the fact that the Non-Refoulement principle itself, as elaborated by Rabbi Isaac Lewin, was premised upon ancient biblical Jewish legal principles of refugee protection. As Lewin explained to the Ad Hoc committee's delegates, the prophet Amos "considered the prohibiting of sending refugees back, to be a binding rule of international law of his time. He once said that God would never forgive Philistine Gaza and Phoenician Tyre for the crime of expelling the Jewish refugees, who had found asylum in their countries, delivering them to the enemy, the Kingdom of Edom" (Ben-Nun 2015a: 104). Knowing full-well that many of the delegates present would ponder the relevance of quotation from the Bible to the affairs at hand, Lewin stressed that in his view, the Non-Refoulement principle mentioned above, was not merely restricted to the tenets of Jewish law, but rather applied universally to all mankind: "It is obvious that since Amos reprimanded Gaza and Tyre, which were not bound by Jewish law; for that sin-he considered their act a violation of international law. We therefore have a precedent for the present convention dating back from the eighth century B.C.E." (Ben-Nun 2015a: 104).

Lewin's address, which drew upon biblical sources, is nowhere to be found in the 1951 Refugee Convention's meticulously ordered official records of that treaty's travaux préparatoires. Given his important role to the drafting of Non-Refoulement, Lewin's observations as to the relevance of Amos's biblical prophecy seems to merit further exploration here, also in light of his later achievement in singlehandedly drafting the UN General Assembly's "Declaration on the Elimination of All Forms of Intolerance and Discrimination Based upon Religion or Belief," which earned him the UN Peace Medal in 1981 (Ben-Nun 2017a: 60).

Lewin's reading of Amos, and his view of it as the first precedent for some sort of international law guaranteeing the protection of refugees, stems from that prophet's referral to the words "whole captivity" and "brotherly covenant" in his prophecy. While in his address Lewin did not mention the exact chapter and verse to which he was alluding, this in fact corresponds to Amos 1:9: "Thus saith the LORD; For three transgressions of Tyre, and for four, I will not turn away the punishment thereof; because they delivered up the whole captivity (גלות שלמה) to Edom, and remembered not the brotherly covenant (ברית אחים)." Lewin's reference to the expulsion of refugees and their deliverance into the hands of their tormentors stems from the Hebrew words גלות שלמה. This translates correctly into the words "entire exiled people." The King James Version mistakenly translates גלות שלמה as "whole captivity." The correct translation, which ought to have been "entire exile," appears only in very modern translations of the Bible such as the Holman Christian Standard (2004). This mistranslation originates in the earliest Greek Septuagint translation of the Old Testament, where גלות was translated into the Greek word $\alpha \iota \chi \mu \alpha \lambda \omega \sigma i \alpha$. This mistranslation was later carried forward into St. Jerome's Vulgate translation of the Bible into Latin (from the Greek). St. Jerome correctly translated the Greek $\alpha \iota x \mu \alpha \lambda \omega \sigma i \alpha$ as the Latin Captivitatem. From there, the path to the King James's Version's "whole captivity" was short.

Yet St. Jerome's translation of $\alpha \iota x \mu \alpha \lambda \omega \sigma i \alpha$ into Captivitatem, and from there into the word "captivity" in the English King James Version was not entirely wrong. Born in Dalmatia, but living most of his life as a monk in Bethlehem, St. Jerome, who spoke fluent Aramaic and Hebrew (in addition to his native Greek and Latin), managed to capture a notion that we today as speakers of modern Hebrew have lost in the meaning underpinning the words "whole captivity" in their correct translation "entire exile" (גלות שלמה). This underlying meaning, which St. Jerome 
understood, was fortunately captured by Rashi in his $11^{\text {th }}$ commentary (Bar-Ilan Aleppo Codex 2020). On the words גלות שלמה in Amos 1:9 Rashi explained, "גלות שלמה: the captivity of Israel for that it shall be complete, so that not one soul would be able to escape, thus performed the people of Tyre who would stand on the roads and at the crossroads, and would capture those fleeing and would then deliver them unto Edom."

As the son of his father (Ahron Lewin, Poland's chief Rabbi), Isaac Lewin could not help but read Amos in its original Hebrew. And like all biblical texts present in an Ultra-Orthodox Haredi house such as his, at the bottom of the biblical text stood Rashi's commentary on the Bible. The responsibility of states was to protect persecuted refugees from not only their tormentors, but also the people who aided their tormentors, that is, those who sent the refugees to be persecuted. With his whole family perishing in the Holocaust in Poland and sitting at the UN Ad Hoc committee's drafting table five years after the end of World War II, Lewin knew all too well how many Jews were turned over to Nazi hands by non-German collaborators within the Nazi-occupied areas of Europe. Rashi's clarification of what took place during biblical times, to which Amos referred in his prophecy, unfolded in front of Lewin's own eyes. It was to this aspect-collaboration between the people of Tyre and the persecutors from Edom in the harming of Jewish refugees, as mentioned by the prophet Amos, and St. Jerome masterfully captured in his Vulgate translation-Lewin eluded when he quoted Amos 1:9 at the UN Ad Hoc Committee's deliberations over the drafting of the Non-Refoulement clause in February 1950.

The severity of the deed executed by the people of Tyre, which earned them Amos's wrath, was not merely the abrogation of some vague ethical principle (not turning refugees back into the hands of their tormentors). Rather, it was the abrogation of a concrete regional diplomatic pact between two previous kings that Tyre reneged upon. Lewin's reference to some early form of international law concerns Amos's reference to the abrogation of a "brotherly covenant" and God's reprimanding thereof. As Rashi explains, these words refer to the regional political pact between the pagan King Hiram of Tyre and the Jewish King Solomon in Jerusalem. In 2 Samuel 5:11, 1 Kings 5:14-25, and 1 Kings 9:10-16, this pact is mentioned whereby both kings referred to one another as "my brother"-hence the "brotherly covenant." The conjunction between the expulsion of exiles back into the hands of their tormentors (Edom) - undertaken by the same people whose king previously sealed this agreement with the Jewish King Solomon and thus the abrogation of an existing regional diplomatic agreement in addition to the infringement upon the more general moral principle of not returning refugees to their tormentors-lay at the heart of Lewin's claim in favor of some sort of a biblical notion of international law.

\section{Jewish Legal Precepts Vis-à-Vis the Unaccountable Death of Refugees: The Beheaded Heifer}

Another point with regard to the Jewish legal view of refugees and their protection concerns their unaccountable death. When refugees die on their plight away from their native homeland in search for safer realms, who is responsible for their death? Set against this important moral question, the views of Jewish law might carry some moderate insights into the unaccounted-for death of refugees currently taking place in Mediterranean Sea.

Interestingly, Jewish law's take on the question of responsibility for the unaccountable death of refugees within a state's immediately controlled vicinity came to the fore rather recently. Following Israel's 1982 invasion of Lebanon, which saw a third of that country's territory under Israel's military rule (including the capital city, Beirut), there was one instance that turned the attention of the Israeli High Court toward the precepts of Jewish law with regard to the attri- 
bution of responsibility for unaccounted dead refugees. The "Kahan Commission" investigated the massacres of Palestinian refugees (primarily women and children) in the Sabra and Shatila refugee camps in West Beirut in September 1982.

Between 16 and 19 September 1982, Lebanese Christian Phalangist forces entered these Palestinian refugee camps situated in West Beirut, which were surrounded by the Israeli Defense Forces (IDF), and massacred between 1,000 and 2,500 civilians there (Fisk 2001: 459-501). Following public outcry in Israel over the fact that these civilians lost their lives under the IDF's watch, who had full control of West Beirut at the time, the Israeli government of Menachem Begin established an investigation commission headed by President of the Supreme Court Yitzhak Kahan, and included Justice of the Supreme Court Aharon Barak and Major General (res.) Yona Efrat. In February 1983, the Kahan Commission found that Israel's Defense Minister, Ariel Sharon; the IDF's Chief of Staff, Raphael Eitan; and Brigadier General Amos Yaron (the local area commander for West Beirut) were all "personally responsible" for allowing the massacres to happen on their watch and were guilty of negligent behavior in failing to stop them (Malone 1985).

One of the most interesting, and unfortunately largely forgotten parts of the Kahan Commission's report concerns the application of the principles of Jewish law to the attribution of responsibility for these dead Palestinian refugees. In an important reference to the general responsibility of magistrates according to Jewish law, the Kahan Commission made what is probably the first full reference to the principle enshrined in the 4th Geneva Convention for Civilians of 1949, which renders an occupier fully responsible for everything that takes place within their occupied territory, and in particular the deaths of innocent civilians in that territory.

According to Jewish law as prescribed by the Torah, under no circumstances can the Jewish state's magistrates abdicate their responsibilities when the corpse of a dead person is uncovered and the circumstances of the death of that person are unknown. This stipulation appears in Deuteronomy 21:6-7. Upon the discovery of a person's corpse the circumstances of whose death could not be determined, the Israelite authorities were compelled to measure the distance from that corpse to the closest city. The magistrates of that closest city, being its elders, were then compelled to take a young heifer (a young female cow), bring it down to the stream closest to the corpse, slaughter it ritually, wash their hands in that mixture of water and the cow's blood, and swear by God's name that their hands did not spill that dead person's "clean blood." Hence forth, the term "beheaded heifer" (עגלה ערופה) came to symbolize the absolute requirement for magisterial responsibility under Jewish law.

This ritual is directly related to the circumstances of war. Deuteronomy 20, which stipulates the laws of war-both of jus ad bellum and of jus in bello in the Torah-is followed immediately by the stipulation of the beheaded heifer because in the ancient world many battles would end with the combatants lying dead in the field-unrecognized.

Leaping forward three millennia, and consistent with the constitutional construction of the modern Israeli state's judicial system, which is a hybrid between British Common Law and Jewish-Talmudic law, the Kahan Commission grounded its conclusion about the responsibility of Israeli state officials in the tenets of this ancient Jewish law. Sharon, Eitan, and Yaron's responsibility was based, so concluded the commission, on the fact that the massacres could well have been anticipated by these dignitaries. The biblical reference to this overall responsibility for the deaths of the Palestinian civilian refugees in Sabra and Shatila was formulated by the Commission in its final report as follows:

A similar indirect responsibility also falls on those who knew of the decision (i.e., to let the Phalangists enter the camps); it was their duty, by virtue of their position and their office, to warn of the danger, and they did not fulfil this duty. It is also not possible to absolve of such 
indirect responsibility those persons who, when they received the first reports of what was happening in the camps, did not rush to prevent the continuation of the Phalangists' actions and did not do everything within their power to stop them ... A basis for such responsibility may be found in the outlook of our ancestors, which was expressed in things that were said about the moral significance of the biblical portion concerning the "beheaded heifer" (in the Book of Deuteronomy, Chapter 21).

It is said in Deuteronomy (21:6-7) that the elders of the city who were near the slain victim who has been found (and it is not known who struck him down) "will wash their hands over the beheaded heifer in the valley and reply: our hands did not shed this blood and our eyes did not see." Rabbi Yehoshua ben Levi says of this verse (Talmud, Tractate Sota 38b): "The necessity for the heifer whose neck is to be broken only arises on account of the niggardliness of spirit, as it is said, 'Our hands have not shed this blood.' But can it enter our minds that the elders of a Court of Justice are shedders of blood! The meaning is, [the man found dead] did not come to us for help and we dismissed him, we did not see him and let him go." (Ben-Nun 2020: 234-235n38)

The last sentence as quoted by the Kahan Commission members from the words of the venerable Talmudic sage Rabbi Yehoshua are crucial here. Under Jewish law, had the deceased person approached the elders of the city ("elders of a Court of Justice" in the sage's words), prior to his death with a request for their assistance, and had those elders turned him away, they would have been partially guilty for the spilling of his blood. By conducting the ceremony of the beheaded heifer, the elders confirm that they really were not approached by this person, nor did they know anything about the circumstances of his whereabouts, or how his death came about.

The relationship between the custom related to the handling of the dead who are unaccounted for and the death of refugees is direct and unequivocal. Under Jewish law, the whole ontological essence of being a refugee stems from the condition of war, which brings about human plight and forced migration. The scenario whereby the body of a dead person is suddenly found, unaccounted for, with no one being able to immediately identify it, is far more plausible to occur to a fleeing refugee under the threat of war than to a normal citizen in times of peace. Nevertheless, this difference between the refugee and the citizen does not absolve a state's magistrates for doing all they can to prevent a person's death, refugee and citizen alike.

\section{Between Jewish Law and the Western Legal Tradition of Roman Law}

Beyond the question as to whether or not both groups ought to be entitled to the same protections and hospitality by their receiving societies, one should note the fact that the differentiation between both groups runs all the way back to some of the most ancient cultural texts. Indeed, such differentiation is not exclusive only to the distinction between different groups of forced migrants, they are even more acute between the migrant and the citizen. A reading of Jewish law's stipulations that demand the protection of both types of displaced persons (war-related and environmentally related ones) and its comparison with similar categories in Roman law, specifically with regard to the state's treatment of its citizens as opposed to its treatment of migrants, might yield some interesting understandings. An examination of these terms in Mandelkern's Concordance to the Bible is revealing.

Published in Leipzig in 1898 and revised several times since, this monumental work, which traces every single word in the Bible and registers where exactly it was written, is distinguished from all previous concordances also by the small notes in Latin (and in Hebrew within the 
subsequent editions published by Schoken) that explain the etymological clarification of the origins of biblical words and their meanings. These notes are a treasure trove for scholars, and have correspondingly set Mandelkern's Concordance in a class of its own as the reference book for etymological biblical scholarship (Mandelkern 1978).

In the biblical world, within which Jewish law emerged, there existed only two categories of residents of a certain place: the citizen (גזרח) and the migrant stranger (גר). Mandelkern clearly saw a juxtaposing opposition between these two terms. He equated the Hebrew word גith its correct Latin translation: peregrinus or hospes (Mandelkern 1978: 259). Commenting on the wזיר wich nowadays means "citizen" in modern Hebrew and he translated as indigenus, Mandelkern commented: "אזרח-a permanent resident from time immemorial—the opposite of ר" (Mandelkern 1978: 27). The explicit contradiction between the citizen and the migrant foreigner also rendered itself relevant to the names of their respective dwellings. The home of a citizen was a domus, from which we today derive the word domicile. The migrant foreignerperegrinus has a residence-a hospes, from where we drive the notion of "hospitality," in other words, the welcome reception of someone not from that place. Observing the characteristic differences between these two different types of dwellings, Cicero, speaking of his emotional experience of being an exile away from Rome, exhorted: tamquam ex hospitio, non tamquam ex domo (as if from a temporary hostel, not from a permanent home) (Cicero: 84).

Beyond the categories of migrant stranger versus citizen we received from the ancients, and over and above the etymological foundations underpinning these categories, there lies the organizational state apparatus that has come down to us from antiquity and by and large the modern nation-state has emulated. Nowadays, in most occidental refugee-receiving countries, when the legal procedures of refugee status determination (RSD) are discussed, we draw a clear distinction between the initial phase conducted by the receiving country's administrative magistrates and a second tier of procedure (in the case of denial of refugee status) that consists of a judicial appeal to a court of law overseen by a judge. This two-staged procedural construct derives from Roman law.

The highest magistrate after the Roman republic's consuls were its praetors. Established in $367 \mathrm{BCE}$, the praetorship (praetor urbanus) was initially intended to take over state duties from the consuls, so as to alleviate their managerial burden, thus charging these lower magistrates with the state's ordinary administrative tasks, as opposed to cardinal policy decisions (Jolowicz 1932: 46). As Herbert Jolowicz explained, the establishment of the praetorship did not mean that the praetor was a judge in the modern sense of the word, since a Roman civil trial always took place in two stages. In the first in iure stage, only the preliminaries and the issue (i.e., the point of law in question) was determined. This stage was conducted by the praetor. The second stage of in iudicem, which consisted of the actual trial, was conducted by a judge (iudex) and not by the praetor (Jolowicz 1932: 46n3).

It was Rome's conquest of foreign lands during the first Punic war (264-241 BCE) that brought it into direct contact and proximity with large swaths of peoples who were not originally from the Apennine peninsula. In $242 \mathrm{BCE}$, the Roman republic established a second type of praetorial magistrate: the praetor qui inter peregrinos ius dicit, "the praetor who decrees between foreigners," or in short, the praetor peregrinus. From that point forward, a clear distinction arose between the praetor urbanus who would determine cases between Roman citizens and the praetor peregrinus who would be charged with administering the state's authority in disputes either between two foreigners (both residing in territories under Roman control) or in disputes between Roman citizens and foreigners. With the conquest of Sicily and Sardinia (227 $\mathrm{BCE}$ ), two more praetor peregrini were nominated and another two were nominated in 197 BCE following the conquest of the Spanish provinces from Carthage-for the administration of that 
foreign territory. Entering the second century BCE, the Roman republic's state apparatus comprised of six praetorships in total: two praetor urbanus for citizens and four praetor peregrinus for foreigners (Jolowicz 1932: 47).

\section{Conclusion}

The distinction between forced migration, which is the result of changes in climatic conditions, and migration triggered by war and persecution is ancient and dates back to the oldest portions of the Jewish Bible and to the fundaments of Roman law. That the origins of our legal regime visà-vis foreigners stems from the interactions between peoples thousands of years ago, be it Jews and gentiles or Romans and others, in the midst of the Mediterranean Sea, along the very same maritime routes sailed nowadays by sea-faring refugees attempting to reach European shores, is interesting from the historian's point of view. The contemporary humane approach of Sicilian fisherman toward African migrants in the Mediterranean, as they fend off pressures by the Italian government not to save refugees in the water, despite the overt threat of prosecution they face should be well noted here (Tondo 2019). That Sicily - the birthplace of Rome's state polices vis-à-vis foreigners, where the first praetor pregrinus was installed 2,200 years ago-is the current place most associated with Italy's reception and hospitality of African migrants crossing that sea denotes how the important traditions of according hospitality to refugees continue to endure (Ben-Nun 2019).

This brings me to the final point concerning Jewish law's view of the rights of the migrant stranger in relation to those of the native citizen. Seeing as the Torah, which dates back roughly to 1500 BCE, preceded Roman law by almost a millennium, there could well be an ancient message that if observed closely, might be pertinent to our day and age. In contrast to Roman law, under Jewish law, the state had a duty not to differentiate the application of its law between the citizen and the migrant stranger. The biblical references to this strict demand of Jewish law to apply the legal code equally between the citizen (אזרח) and the migrant stranger (גר) are clear and incontrovertible. "One law shall be to him that is homeborn (אזרח), and unto the stranger (ג) that sojourneth among you" says God in the very first parasha of the book of Exodus (Ex. 12:49). Possibly the most famous passage in the Torah concerning this equation is to be found in Leviticus: "The stranger that dwelleth with you shall be unto you as one born among you, and thou shalt love him as thyself; for ye were strangers in the land of Egypt: I am the Lord your God" (Lev. 19:34). To ancient Jewish law, the human categories of citizen and migrant stranger were obvious, since these were universal categories of people existent in all human societies. Yet it was against the prevalent legal codes of many (if not all) the peoples surrounding the Israelites that the Jewish Torah chose to strike out the possibility of two parallel legal codes to be applied within the same society-one for citizens, the other for migrants. The universality of the law meant precisely that. It had to be applied equally to all. If one were to paraphrase Roman law onto Jewish law, then Judea would only have a praetor urbanus who would administer the law equally to citizens and foreigners alike.

As both I and others have shown, far from being alien to modern international law, Jewish-Talmudic legal ideas were mutual to many Jewish international jurists who took on cardinal drafting roles of the international system's humanitarian treaties during the twentieth century (Ben-Nun 2021; Loeffler and Paz 2019). Ancient Jewish law, which equated the rights of the citizen and the migrant, implied ipso facto an equation of the rights of all forced migrants, be their reason for refuge climatic or war related. This ancient approach might well hold relevance for today's debates over the distinctions between these different migrant categories. 


\section{ACKNOWLEDGMENTS}

A draft of this article was first presented at the Max Planck Institute for the Study of Religious and Ethnic Diversity in Göttingen in October 2018. The author is indebted to Benjamin Boudou, Hans Leaman, and Maximillian Scholz for their help and support during its writing. The author is also indebted to the anonymous reviewers of this article: thank you for your good and thoughtful comments, which have improved this manuscript considerably. Finally, the author wishes to acknowledge funding received during the preparatory stages of this article under Hablitation grants from the Leibniz Institute GWZO and the Leibniz Science Campus EEGA (2018-2019). Support for its final revision stages was provided by the EU's PREVEX Project (EU Grant Agreement 870724).

GILAD BEN-NUN is a senior scholar at the Leibniz Institute GWZO and a senior lecturer at Leipzig University's Research Centre Global Dynamics, where he teaches Global Studies and the History of International Law. A former EU-Marie Curie Individual fellow at Verona University's law faculty and a former Ford Foundation Fellow at UNIDIR, his monograph on Israel's reception of African refugees won the 2017 US National Jewish Book award. In 2020, he was awarded the visiting professorship for Israel Studies at Munich's Ludwig Maximilian University, in association with the Israel Institute and the American University in Washington, DC. In 2021 he was awarded the Alfred Grosser Chair at Sciences-Po in Paris. Email: gilad.ben-nun@uni-leipzig.de

\section{REFERENCES}

Alston, Philip. 2019. UN Special Rapporteur for Extreme Poverty, Report on Climate Change, Extreme Poverty and Human Rights, UN Doc. A/HRC/41/39. https://undocs.org/A/HRC/41/39.

Bar Ilan University Aleppo Codex Database. 2020. https://www.mgketer.org/mikra/17/6/1/mg/0.

Ben-Nun, Gilad. 2014. “The Israeli Roots of Article 3 and Article 6 of the 1951 Refugee Convention.” Journal of Refugee Studies 27 (1): 101-125.

Ben-Nun, Gilad. 2015a. "The British-Jewish Roots of Non-Refoulement and its True Meaning for the Drafters of the 1951 Refugee Convention." Journal of Refugee Studies 28 (1): 93-117.

Ben-Nun, Gilad. 2017a. Seeking Asylum in Israel: Refugees and the History of Migration Law. London: I.B. Tauris.

Ben-Nun, Gilad. 2017b. “The Expansion of International Space: UNHCR's Establishment of Its Executive Committee ('ExCom')." Refugee Survey Quarterly 36 (3): 1-19.

Ben-Nun, Gilad. 2019. "Antidotes to Extremism: Africa's Refugee Hospitality Paradigm." In Contemporary Africa and the Foreseeable World Order, ed. Francis Onditi, Gilad Ben-Nun et al., 113-132. Lanham, MD: Rowman \& Littlefield, Lexington Books.

Ben-Nun, Gilad. 2020. The Fourth Geneva Convention for Civilians: The History of International Humanitarian Law. London: Bloomsbury Books.

Ben-Nun, Gilad. 2021. "How Jewish is International Law?" Journal of the History of International Law 2. https://doi.org/10.1163/15718050-12340171.

Cicero, Cato Maior de Senectute [Cato the Elder: On old age]. http://penelope.uchicago.edu/Thayer/E/ Roman/Texts/Cicero/Cato_Maior_de_Senectute/text ${ }^{\star}$.html. Latin text at: https://www.forumroma num.org/literature/cicero/sen.html\#84.

Einarsen, Terje. 2011. “The Drafting History of the 1951 Convention and the 1967 Protocol." In The 1951 Convention Relating to the Status of Refugees and its 1967 Protocol: A Commentary, ed. Andreas. Zimmermann, Jonas. Dörschner, and Felix. Machts, 37-74. Oxford: Oxford University Press. 
Fisk, Robert. 2001. Pity the Nation: Lebanon at War (updated edition). Oxford: Oxford University Press. Giladi, Rotem. 2015. "A Historical Commitment? Identity and Ideology in Israel's Attitude to the Refugee Convention 1951-4." The International History Review 37 (4): 745-767.

Glynn, Irial. 2012. "The Genesis and Development of Article 1 of the 1951 Refugee Convention." Journal of Refugee Studies 25 (1): 135-140.

Jewish Publication Society. 1917. The Jewish Bible with English Translation. https://www.mechon-mamre . org/p/pt/pt0114.htm

Jolowicz, Herbert. 1932. Historical Introduction to Roman Law. Cambridge: Cambridge University Press.

Kälin, Walter. 2016. UN Representative of Secretary-General on the Human Rights of Internally Displaced Persons and the Nansen Initiative's Chairmanship Envoy, lecture at Harvard law School, 4 November. https://www.youtube.com/watch?v=iO6ocjezJgk.

Königseder, Angelika, and Juliane Wetzel. 2001. Waiting for Hope: Jewish Displaced Persons in Post-World War II Germany, Evanston, IL: Northwestern University Press.

Loeffler, James, and Moria Paz. 2019. The Law of Strangers: Jewish Lawyers and International Law in the Twentieth Century. Cambridge: Cambridge University Press.

Malone, Linda. 1985. "The Kahan Report, Ariel Sharon and the Sabra-Shatilla Massacres in Lebanon: Responsibility under International Law for Massacres of Civilian Populations." Utah Law Review 373 (2): 373-433.

Mandelkern, Salomon. 1978. Veteris Testamenti concordantiae Hebraicae atque Chaldaicae, (4th) ed. with Margolin's corrections. [In Hebrew.] Tel Aviv: Schocken [orig. Leipzig: Veit Verlag, 1896].

McAdam, Jane, ed. 2010. Climate Change and Displacement: Multidisciplinary Perspectives. London: Hart Publishers.

McAdam, Jane. 2011. Do Climate Change "Refugees" Exist? Lecture at the University of New South Wales, 21 September. https://www.youtube.com/watch?v=c7fICabMHzg.

McAdam, Jane. 2012. Climate Change, Forced Migration, and International Law. Oxford: Oxford University Press.

Nansen Initiative for Forced Displacement Related to Natural Disasters. 2015. https://www.nanseninitia tive.org/global-consultations/.

Tondo, Lorenzo. 2019. "Sicilian Fishermen Risk Prison to Rescue Migrants: 'No Human Would Turn Away." The Guardian, 3 August.

Twersky, Isadore. 1997. "Rashi: French Religious Scholar." Encyclopaedia Britannica. https://www.britan nica.com/biography/Rashi.

UNHCR 2018: Global Trends of Forced Displacement. https://www.unhcr.org/dach/wp-content/ uploads/sites/27/2019/06/2019-06-07-Global-Trends-2018.pdf.

Yad Vashem. 2020. “She'arit Hapleta (the Surviving Remnant).” https://www.yadvashem.org/odot_pdf/ Microsoft\%20Word\%20-\%207797.pdf. 